\title{
A magyarországi wellness-szállodák marketingkommunikációjának új trendjei
}

\author{
Szerzők: Dunai Tamás ${ }^{1}$ - Lengyel Nikolett Lilla²
}

"Pihenni bárhol tud! Nálunk újjászületik!" - szól a Caramell Premium Resort szálloda hívószava, amely a hotel minden megjelenésekor felbukkan, s amely a turisztikai szolgáltató vendégekért való küzdelmének egyik eszköze. De mégis hol, milyen új eszközökön keresztül juttathatók el ezen szlogenek a potenciális látogatókhoz? A tanulmány a magyarországi wellness-szállodák marketingkommunikációjában megjelenó online eszközök rendszerezésére vállalkozik. A központi vonatkoztatási keret ellenére azonban e technikák használhatósága minden bizonnyal más, akár nem turisztikai jellegú termékekre is kiterjed.

Kulcsszavak: online marketing, Public Relations, wellness, szálloda, imázs.

\section{Bevezetés}

A kommunikációs technikák jelentóségének növekedése erőteljes hatással van a világ turizmusára, amelynek terei a mobilitás korlátainak egyre szélesebb körú lebontásával folyamatosan növekednek. A turizmus azon iparágak közé sorolható, amelyeknek ma már minden szegmense, tevékenysége kapcsolódik az online kommunikációs eszközökhöz (KISS 2018), kezdve a turisztikai szolgáltató és termékei bemutatásától, illetve ezek reklámozásától, az utazás megtervezésén és az üdülés alatti platformhasználaton át, az utólagos kapcsolatfenntartásig a vállalkozás és vendége között.

A hagyományos marketingkommunikációs eszközök széles skálájának bemutatásával számos szakirodalom foglalkozik. Azonban a kérdés kategorikus megválaszolásával - hogy melyek azok az új online platformok és eszközök, amelyek a vállalkozások marketingjében ma már nagyobb arányban vannak jelen a hagyományos technikákkal szemben - jóval kevesebb ${ }^{3}$. Az új technikák jellemzőinek és gyakorlati használhatóságának megismerése a szolgáltatóknak segítséget nyújt a potenciális vendégek biztosabb eléréséhez, míg a

\footnotetext{
${ }^{1}$ egyetemi tanársegéd, Szegedi Tudományegyetem, duntam@gmail.com

2 mesterszakos hallgató, Szegedi Tudományegyetem, niki19951126@gmail.com

${ }^{3}$ Ezen a területen a közelmúltban történt előrelépés: a 2018-ban először megrendezett Nemzetközi Turizmusmarketing Konferenciához kapcsolódó, online kiadott tanulmánykötet (Generációk a turizmusban) több, a turizmusra jellemző, marketing szempontból jelentős új jelenséget is bemutat.
}

fogyasztóknak kelló ismeretet ad ahhoz, hogy a mindennapos marketingüzenetekkel való találkozásuk során azokat racionálisan (ne csak érzelmeikre hagyatkozva) tudják kezelni.

A tanulmány célja, hogy feltérképezze azokat az online platformok nyújtotta lehetôségeket, amelyek a vállalkozások számára marketingkommunikációs, azon belül is imázsformáló potenciállal bírnak. Írásunkban nem foglalkozunk részletesen a marketing minden elemével (4P: termék, árazás, elosztási csatornák, marketingkommunikáció), azok releváns elemeit inkább csak a marketingkommunikáció egyik eszközéhez, a Public Relationshöz (PR) kötve tárgyaljuk. ${ }^{4}$ A PR területén fókuszpontunk az imázsformálásra esik.

\section{A téma elméleti kerete}

\subsection{A WELLNESS HELYZETE HAZÁNKBAN}

A turizmus globális térnyerése, azon belül az egészségturizmus jelentóségének növekedése, mind az állam ${ }^{5}$, mind a vállalkozások részéról jelentôs beruházásokat indított el. Az egészségturizmus ${ }^{6}$ részeként, a wellness fogalmának és tevé-

\footnotetext{
${ }^{4}$ Dolgozatunk kommunikáció- és médiatudományos szempontból íródott. Az online marketing igen jelentős része a különböző platformokon történő reklámozás is, azonban a terjedelmi korlátokra való tekintettel ennek bemutatására nem vállalkozunk.

${ }^{5}$ A Nemzetgazdasági Minisztérium 2013-ban kidolgozott, a 2014-2024-es időszakra vonatkozó Nemzeti Turizmusfejlesztési Koncepciójában prioritásként fogalmazta meg az egészségturizmushoz kapcsolódó attrakciófejlesztéseket, amelyek sikerességével Magyarország 2024-re - a tervek szerint - az egészségturizmus több területén Európa kiemelkedő országa lesz (KOZMÁNÉ 2017). ${ }^{6}$ Az egészségturizmus másik összetevője a gyógyturizmus. A wellness és a gyógyturizmus összekapcsolódása hívta életre a medical wellness jelenségét (LŐKE et al. 2016).
} 
kenységének elterjedése a 2000-es évek elejétól volt megfigyelhetó hazánkban (BOROS et al. 2012). A wellness a stresszkezelés és a betegségmegelózés egy formája, amely az ember testi, lelki és szellemi állapota egyensúlyának megteremtését túzi ki céljául. A wellness mint turisztikai termék vonzereje a céljából fakad: a mindennapos monotonitás és az azzal egyenes arányosságban növekvő egészségtudatosság hatására mind inkább előtérbe kerül a rekreáció, a prevenció és az időról időre történó testi-lelki feltöltődés fontossága, melyek turisztikai szolgáltatásokkal párosulnak. A 2000-es évekbeli fürdőfejlesztések hatására olyan szálláshelyek jöttek létre, amelyek komplex szolgáltatáscsomagjukkal képesek voltak az utazók szabadidős és egészségmegőrzésre irányuló igényeit kielégíteni (LÓKE et al. 2016). Bár a KSH a wellness szállodák számáról csak 2013-ig közölt adatokat (hisz akkor a kötelezô minősítési rendszer megszúnt, így ezután a szállodák már nem voltak egyértelmúen kategorizálhatóak), a 2004 és 2012 közötti időszak kiválóan reprezentálja a wellnesshotelek számának rohamos növekedését. 2012-ben a kereskedelmi szálláshelyek 8\%-a wellnesshotel volt, ami 164 egységet jelentett, s a szálláshelyek összesített bruttó bevételének mintegy $21 \%$-a csak a wellness szektor teljesítményének volt betudható. Hivatalos statisztikák hiányában a LŐKE és szerzőtársai (2016) által készített tanulmányra hivatkozunk, amikor azt állítjuk, hogy 2016-ban 178 wellness-szolgáltatást nyújtó szálloda múködött Magyarországon (LŐKE és szerzőtársai a hotelek weboldalait elemezték, hogy azok kínálnak-e wellness-szolgáltatást). Ez a szám az eltelt három év alatt feltehetően növekedett. 2016-ban a 178 szálloda közül 45 viselte a wellness elnevezést, amelyekból azonban csak két létesítményt minősített a Magyar Szállodák és Éttermek Szövetsége (MSZÉSZ) valóban wellness-szállodává (az állami szabályozás megszúnése után a minősítési feladatot az MSZÉSZ végzi). Látható tehát, hogy bár sok hotel nem érzi szükségét a minősítésnek és a wellness hivatalos elismertetésének, az elnevezés vendégvonzó hatását felismerik. A wellness-trend elterjedése és sokszínúsége így kiváló alapot nyújt a marketingkommunikációs lehetőségek feltérképezéséhez.

\subsection{A MARKETINGKOMMUNIKÁCIÓ ÉS A PUBLIC RELATIONS SZEREPE}

A wellness területén az egészséges életmódról való szubjektív és igen szerteágazó gondolkodásmódok egyre többféle szolgáltatást hívnak életre, amellyel párhuzamosan a piaci verseny is erősödik. Ennek mozgatórugója pedig immáron már nem a termékjellemző́k és elônyök bemutatása, hanem sokkal in- kább az egyes termékekhez kapcsolódó érzelmek és hangulatok - vagyis az elérhetó élményminőség - hangsúlyozása. Ahogyan azt KULCSÁR és GROTTE (2018) tanulmányukban hangsúlyozzák, a fogyasztóknak a szolgáltatásokról kialakított értékítéletében megjelennek ugyan a racionális döntésekből adódó tényezők, mint például az ár-érték arány, azonban az affektív dimenziók jobban érvényesülnek. Ebbe a kategóriába tartoznak például a hangulatok, az érzések, a kapcsolatok és a megtapasztalt élmények ${ }^{7}$.

A szoros piaci verseny sikerességét az egyes vállalkozások esetében a hatékony marketingtevékenység segíti eló, amelynek a fogyasztókkal kapcsolatos legközvetlenebb része a marketingkommunikáció. A marketingkommunikáció célja, hogy a szolgáltató üzenetét hatékonyan közvetítse a fogyasztó felé, megértesse magát vele, ezzel pedig hosszú távon vásárlást és elköteleződést generáljon (LÓRINCZ-SULYOK 2017). A turizmus rendszerén belül a marketingkommunikáció a létfenntartás alapja a szolgáltatók számára. A szolgáltatások jellemzóje többek között a megfoghatatlanság, amely a fogyasztó szemszögéből azt jelenti, hogy az adott turisztikai termék előzetesen nem próbálható ki, nem fogható kézbe. Ezt az akadályt szükséges tehát a vállalatnak a promóció eszközeivel áthidalnia: a minőség és megbízhatóság üzeneteken keresztüli hangsúlyozása által, illetve a turisztikai termék megfelelő szintú bemutatásával.

A vállalat iránti fogyasztói elköteleződés kialakításának egyik leghatékonyabb módja az imázsépítés, amely a PR kiemelkedóen fontos területe. A szolgáltató ezen tevékenységének célja, hogy az emberek pozitív gondolatokra, érzésekre asszociáljanak, bizalmat érezzenek az adott szervezet termékeivel, szolgáltatásaival, valamint általános tevékenységével kapcsolatban. A PR fontos jellemzője - amely az online tér lehetóségeit figyelembe véve még hangsúlyosabb - a kétoldalú kommunikáció, amely ugyancsak a bizalmat erósíti. A tevékenység magában foglalja az aktuális környezeti hatások megfigyelését és az azokra adott reakciókat, valamint célja, hogy fenntartsa a vállalat erősen profitorientált tevékenysége és a fogyasztói jó megítélés közötti egyensúlyt (KITCHEN 1997). A jó imázs felépítése hosszú és lassú folyamat, állandó odafigyelést, törődést igényel a PR szakemberek részérôl. A szállodák esetében kiemelten fontos ezen tevékenység, hiszen a turisztikai szektorra nem jellemző a kimagaslóan lojális fogyasztói tábor kialakulása. Ez főleg az Y és a $Z$, vagyis a mostani fiatal, legna-

\footnotetext{
${ }^{7} \mathrm{Az}$ élményszerüség fontossága leginkább az Y és a $\mathrm{Z}$ generációban figyelhető meg, amelynek tagjai a termékek személyre szabottsága és az információk gyorsasága mellett főleg ezen tényező alapján döntenek és alkotnak ítéletet az adott szolgáltatásról (GROTTE - KULCSÁR 2018).
} 
gyobb gazdasági potenciállal rendelkező generációkra jellemző, akik nem egy adott márka termékeit vásárolják meg (jelen esetben nem mindig egy adott szállodába térnek vissza), hanem olyan termékeket keresnek, amelyek cégtől függetlenül a leginkább megfelelnek az aktuális elvárásaiknak. Ezen tevékenységükre időt is szánnak: saját „,kutatást” végeznek vásárlási döntéseik előtt. Kitûnik tehát, hogy amint az új, úgy a visszatérő vendégek számának növeléséhez is ugyanúgy (ha nem jobban) szükségeltetik az imázsépítő tevékenység fokozása a szállodák részéről (GROTTE-KULCSÂR 2018).

A PR és a marketing kapcsolata tudományos és szervezeti körökben sem tisztázott, s ezen téma feszegetése jelen tanulmánynak nem is célja. GYULAVÁRI (2011) azonban úgy véli, hogy a PR-nak a marketingkommunikáció részeként való meghatározása abban az esetben helytálló, amenynyiben a vállalat profitorientált tevékenységet folytat, hiszen a múködés ezen formájában a PR egyes eszközei is jelentős segítségül szolgálhatnak a cél elérésében. A wellness-szállodák márpedig profitorientált vállalatok. Ezen felül az internet és az azzal egy időben megjelenó részvételi kultúra sajátosságai, úgymint a kétirányú kommunikáció, a szúk piaci szegmensek különleges igényei, valamint a választási lehetôségek megnövekedett volta, irrelevánssá tették a hagyományos marketing tömegeket megcélzó tevékenységét. A vállalat és a vendég közötti dialógus kialakításában, a különleges igények felismerésében, valamint a szolgáltatás tömegból való kiemelésében a PR-nak nagy szerepe van. Ez alapján jelen tanulmány a PR-t a marketingkommunikáció részének tekinti, annak releváns elemeit hangsúlyozva (mint például az imázst), amelyek egyik hosszú távú célja - a többi marketingkommunikációs eszközhöz hasonlóan az eladások számának növelése.

\subsection{RÉGI ÉS ÚJ CSATORNÁK - AZ INTEGRÁLT MARKETINGKOMMUNIKÁCIÓ JELENTŐSÉGE}

A PR és a marketing ilyetén összeolvadása az integrált marketingkommunikáció fogalomkörébe tartozó jelenség. Az integrált marketingkommunikáció a kommunikációs eszközök, promóciós technikák minél sokrétúbb felhasználását és az azokon keresztül közvetített üzenetek összehangolását jelenti, amelybe a fenti megállapítások szerint a PR tevékenység harmonizációja is beletartozik (egyes megközelítések szerint az integrált marketingkommunikáció kifejezetten a marketing és a PR egybeolvadását jelenti). Mind a turizmusban, mind pedig a termékek más piacain célszerú az integrált kommunikáció használata. Ennek oka, hogy a fogyasztók manapság már nem különböztetik meg az egyes kommunikációs csatornákat, az egy adott szervezettől érkező üzeneteket egy egészként kezelik. Az integrált marketingkommunikáció célja ez alapján az, hogy az adott szervezet arculati elemeit, valamint a szolgáltatásokról közvetített üzeneteit összehangolja, úgymond közös nevezőre hozza. Az integrált kommunikáció használatakor is beszélhetünk a stratégiai és taktikai célok ilyen formában történő megvalósításáról, vagyis az eladások növeléséról és a fogyasztói elköteleződés kialakításáról. A csatornák (televízió, rádió, nyomtatott sajtó, internet és közvetlen eladás) egymástól különböző lehetôségeit kihasználva, ugyanakkor az üzenet terén az egységességre, stílusosságra törekedve egy olyan jól fókuszált ${ }^{8}$ és hatásos marketingkommunikációs metódust alakíthatunk ki, amely rövidtávon magasabb eladási arányt, hosszú távon erôs ügyfélkapcsolatok kiépülését, valamint a fogyasztóknak a szolgáltató felé való elköteleződését indikálja. Az integrált marketingkommunikáció hiánya az imázs inkoherenciájához vezethet, amely nem támogatja a turizmus területén amúgy is nehezen kialakítható vendéghúséget (LŐRINCZ-SULYOK 2017, MEERMAN SCOTT 2015, KITCHEN-BURGMANN 2010).

Tanulmányunk célja az online lehetôségek számbavétele, amelyek jobb megértéséhez vissza kell nyúlnunk oda, ahol azok gyökereznek. A Web 2.0 fogalma főként TIM O'REILLY-hez köthető, aki még inkább gazdasági, mintsem generációs szempontból közelítette meg a webes felületek átalakulását. Ennek ellenére a fogalom használatakor már ő is olyan platformokról beszél, amelyek a közösségre, a közösségi tartalomgyártásra és fogyasztásra alapozva szerveződnek, vagyis valamilyen formában a felhasználók közötti kooperációra épülnek (O'REILLY 2007). A marketingkommunikáció szempontjából a közösségiségnek számos hatása figyelhetô meg a fogyasztói oldalon. Ilyen például a véleménynyilvánítás szabadságának magasabb foka, az amatőrök általi tartalomgyártás megnövekedett szerepe (amely akár marketing jelentőséggel is bírhat), vagy a vendégek döntési szabadságának jelentős kitágulása (POWERPHILLIPS-WREN 2011). A Web 2.0 azonban a szolgáltatóknak is kiváló lehetőséget teremtett többek között a költséghatékony kommunikációra, hiszen

\footnotetext{
${ }^{8}$ A manapság legelterjedtebb analizáló módszer a big data elemzésre alapuló rendszerek használata, amelyek többek között az alább tárgyalt közösségi média felületeken jelen levő felhasználók adatait és cselekvéseit (kedvelést, kattintást, görgetési sebességet stb.) is feldolgozza. Általuk a vállalkozásoknak lehetősége nyílik szük célszegmensek megszólítására, az üzenetek pontos elhelyezésére, személyre szóló szolgáltatáscsomagok összeállítására. A big data elemzés előnye a folyamatosságban rejlik, valamint abban, hogy a kutatás itt már nem véleményeken, hanem konkrét cselekvéseken alapszik, amelyek által megbízhatóbb információkat nyújt (ÁRVA-DELI-GRAY 2018)
} 
a korábbi tömegmarketing helyett a célcsoportok szerinti kommunikáció is lehetővé vált, valamint megszúnt a kampányok idejének korlátozottsága, amely a hagyományos tömegmédiumok múködésének szabályaiból adódott. Emellett a korábban csak a hagyományos médiumokra támaszkodó, zártnak túnô PR-tevékenység is egy nyitottabb térben fejtheti ki hatását blogok, hírek, imázsvideók és más online tartalmak segítségével, amelyek a szóródás elkerülése végett célzottan közvetíthetőek a vendégek felé (MEERMAN SCOTT 2015).

Habár a tanulmány célja a Web 2.0-val egy időben és azóta megjelenő platformok és marketingkommunikációs eszközök bemutatása, egy vállalat marketingkoncepciójának kialakítása során nem szabad megfeledkezni a hagyományosnak tekintett kommunikációs csatornákról és eszközökrôl sem, mint például a nyomtatott sajtóban megjelenő vagy televíziós imázsreklámokról. Egyrészt, mert az online platformok új eszközei funkciójukban gyakran hasonlítanak egy-egy régi társukhoz, s megjelenési formájukban különböznek csak, így a hagyományos csatornák és eszközeik kiváló vonatkoztatási alapot adnak az újdonságok alaposabb megismeréséhez. Másrészt, a hagyományos technikák kommunikációbeli relevanciáját erôsítendő, említsük meg itt SCHANZE (2001) a médiumok modellszerú alapmozgásának elvét. A jelenség ${ }^{9}$ a marketingkommunikáció elemeire is kitúnően lefordítható, e tekintetben a marketingkommunikáció modellszerú alapmozgásán azt kell érteni, hogy az újonnan belépó technikák, mint az online világ lehetôségei, a hagyományos marketingkommunikációs csatornákat és a hozzájuk kötődő eszközöket nem szorítják ki, sokkal inkább azok mellé lépnek. Az új csatorna és eszközeinek megjelenése ugyan hatással van a hagyományos csatornák helyzetére, lehetőségeire és jelentőségére, azonban azok erősítik is egymást. A szolgáltatónak lehetősége nyílik arra, hogy átadni kívánt üzeneteit a leginkább releváns csatornán - annak lehetôségeit kihasználva - a leghatásosabb formában juttathassa el fogyasztóihoz. Ezen felül a médiatartalom megjelenésében is változás figyelhetô meg, hiszen az új médiában a különbözô tartalmak hosszabb ideig érhetôek el: például a televízióból való eltûnésük után is fellelhetőek (visszakereshetőek) az online térben.

Az integrált marketingkommunikáció magával vonja azt, hogy az egyes eszközök nem konkrétan egy eredmény elérésére fókuszálnak: változó mér-

\footnotetext{
„Eszerint egy új médium megszületése sohasem teszi feleslegessé a már előtte létezett médiumok egyikét sem: nem a helyükbe, hanem melléjük lép, egyúttal újradefiniáltatja velük a helyüket, a jelentőségüket és a lehetőségeiket. (...) Kétségtelen azonban, hogy az újabb és újabb médiumok elkülönülése mindig szerepük újragondolására, sok esetben elkeseredett ellenállásra késztette a régebbieket” (SZAJBÉLY 2005).
}

tékben, de az eladások növeléséért és az imázsformálásért egyaránt felelnek. Ebból adódóan a tanulmány során, bár az eszközök imázsformálásra alkalmas funkcióit vesszük sorra, gyakran megjelennek a konvencionális marketingeszközök is, mint például az eladásösztönzés. Az online marketingkommunikációs lehetôségek ismertetésekor azon platformokat tekintjük át, amelyek hazánkban is ismert és gyakran használt internetes oldalak. A tanulmány célja a hazai trendek számbavétele, a platformok felépítésének és - főleg a PR területén való - gyakorlati használhatóságának bemutatása.

\section{Az online platformok és eszközeik}

\subsection{AZ EGYEDISÉG KIFEJEZÉSÉNEK FELÜLETE: A WEBOLDAL}

Az online erősítendő imázs alapvetó feltétele a szálloda minél több helyen való megjelenése. A jelenlét alapja pedig a hotel jól felépített weboldala. A weboldalak létét ma már meg sem kérdőjelezzük, tekintve, hogy a közvetlen online foglalás fontos értékesítési csatornává vált ${ }^{10}$. Egy jól kialakított honlap magában foglalja a marketing-mix négy elemét, vagyis a termékeket, az árakat, az elosztási csatornát (jelen esetben az online foglalási rendszert), amelyeket hatékony (és hatásos) marketingkommunikációs eszközök támogatnak. Emellett egy jó weboldal a vállalkozás imázsának online megnyilvánulása is egyben (SZIVA 2016).

A weboldalak megfelelő funkcionálásához több összetevőre van szükség, jelen esetben öt elemet tárgyalunk: a szálloda általános bemutatását, a fogyasztói reakciók kezelését, a foglalási információk minőségét, a szálloda környezetében megtalálható attrakciók bemutatását, valamint az interakciós lehetőségek feltüntetését (QI 2016). A balatonfüredi Hotel Silverine Lake Resort weboldalát ${ }^{11}$ megnyitva olykor egy pop-up reklámmal találkozik a látogató, amely a legaktuálisabb ajánlatot hirdeti. Az ablakot bezárva a hotel által sugallni kívánt hangulatokat megjelenító fotók foglalják el a főoldal központi részét, amelyekkel már rögtön az elérhetô élményminőséget hangsúlyozzák. A menüsor magában foglalja a "Hotel” menüpontot, amelyen belül a szobatípusokat, a gasztronómiai lehetóségeket, valamint egyúttal a környező programokat,

\footnotetext{
${ }^{10}$ Az olyan foglalási weboldalak mellett, mint a Booking.com vagy a Szallas.hu, amelyek összefoglalják a szállodák ajánlatait és közvetett online értékesítés formájában közvetítik azokat a fogyasztók felé. Az értékesítésen túl ezen oldalak imázserősítő funkcióval is bírnak, hiszen az öszszegyüjtött értékelések révén a vendégvélemények egyik leghitelesebb forrásának tekinthetők.

${ }^{11} \mathrm{https} / / /$ silverinelake.hu/hu
} 
Balatonfüred látványosságait is feltérképezheti a potenciális vendég, attrakciótípusok szerinti bontásban. Emellett a környező települések látnivalói is megjelennek, valamint naptárszerúen megismerhetóek a városban megrendezett programok. A szálláshely környékének potenciális vendégvonzó funkciója többek között abban rejlik, hogy a színes programlehetóségek megerósíthetik a fogyasztót utazási döntésében. A menüsor fóbb pontjai még az „Ajánlataink", a „Wellness” és a „Rendezvény" menüpontok, amelyek a hotel elsődleges tevékenységeit jelölik. A szolgáltatásokat részletesen bemutatják, azokat képekkel illusztrálják. A menüpontok között megtaláljuk a "Galériát" is, ezen felül az oldal alján egy virtuális sétára invitálják a látogatót. A 360 fokos képkészítés hatékony módja a szálloda bemutatásának. Segítségével a hotel egyes részlegei, úgymint az étterem, a wellnessrészleg vagy a szobák is megtekinthetőek - életszerú bemutatásban. Mivel a szálloda felszereltsége gyakran elsődleges szerepet játszik az utazási döntésben, ez akár központibb helyet is kaphatna a honlapon. Az audiovizuális és képi tartalmak kiválóan ellensúlyozzák a szolgáltatások megfoghatatlan jellegét, ezek a kontentek megfelelóen reprezentálják a szálloda belső és külső környezetét, valamint hangulatát.

A központi kép alatt találjuk a foglalási rendszert is, amely letisztult és öt lépésból áll (az érkezési idôpont és a személyek számának megjelölése, a szobatípus, valamint a bekészítések kiválasztása, illetve a személyes információk megadása). A foglalás során minden aloldalon feltüntetnek egy a segítségnyújtásra irányuló telefonszámot, amely az interakció és így a személyes kapcsolat kialakulását, a bizalom növelését segíti. A foglalási rendszer magában foglalhat a szokásos lépéseken felül olyan részinformációkat gyúitố menüpontot is, amelyen belül a szolgáltató például arról érdeklődhet, hogy a látogató honnan hallott a szállodáról. Ennek kiváló példája az Accent Hotels hotellánc ${ }^{12}$ tagszállodáinak foglalási rendszere. A kérdés célja többek között (a megadott válaszok, mint például „internetes keresőkön”, „újság, magazin”, segítségével), hogy a vállalat felderítse a vendég preferált információforrásait, $\mathrm{s}$ a késóbbiekben ezen adatok birtokában a megfeleló csatornákon elhelyezett reklámokkal visszatérésre buzdítsa. Amennyiben valamelyik válaszlehetőség kiemelkedően sok jelölést kap, az a későbbiekben iránymutatásként szolgálhat a vezetőknek a potenciális vendégek megtalálásához. Ezek a kis piackutatások nagyban hozzájárulnak a marketingstratégia továbbfejlesztéséhez, hiszen az összegyújtött információk a szállóvendégektól érkező primer adatok.

\footnotetext{
${ }^{12}$ https://accenthotels.com/hu
}

A foglalási rendszerben feltüntetett telefonszámon kívül a weboldal alján megtaláljuk a Facebook és az Instagram linkeket, valamint a "Kapcsolat” menüponton belül a vezetőség tagjainak elérhetőségét. Ezek a széles körú interakciós lehetőségek erósen befolyásolhatják a vendégekben kialakuló képet a vállalkozásról, és bizalmat generálhatnak, hiszen a közvetlen elérhetőség a hitelességet, a személyes kapcsolat prioritását, s mindenekelótt a vendégközpontúságot tükrözi a szálloda részéről. Bár a weboldalon nincs közvetlen lehetőség a vendégvélemény megosztására, a "Vendégkönyv" menüpontban a látogató a már elszállásolt utazók véleményét olvashatja el.

A blogolási tevékenység kifejezetten hatékony lehet a wellness-szállodák esetében. A tartalommarketing ezen területén, a blogbejegyzések által, a szállodának lehetôsége nyílik arra, hogy például egyes díjak elnyerésének körülményeit, rendezvények lebonyolítását vagy alapjában véve mindennapi tevékenységét a saját szemszögéből közvetlenül a vendégekhez szólva - megoszthassa, ahogy azt a Hotel Silverine Lake Resort is teszi. A NaturMed Hotel Carbona szálloda honlapján ${ }^{13}$ a blogfelület mintegy magazinként funkcionál (Harmónia Magazin), amelynek cikkei a manapság igen elterjedt és a wellnesshez szorosan kapcsolódó „,beauty” (egészség, szépség, életmód) témával foglalkoznak. A magazin egy újabb profilt biztosít a hotelnek, s egyben az imázs egyik elemét, a hitelességet erósíti azáltal, hogy a szálloda wellness-tevékenységét a szakmában kompetensként prezentálja. Ez a fajta tartalommarketing ezenfelül a találati helyekben is jobb eredményeket produkál a szálloda számára. A hotel mindennapjainak közvetett bemutatására szolgálhat továbbá a média munkatársai számára kialakított menüpont, ahol a hotelról készített sajtóanyagokat találhatja meg az újságíró. Az imázsépítés sikeréhez nagyban hozzájárul a megfelelóen kialakított sajtókommunikációs tevékenység, a jól múködő sajtókapcsolati háló és a minél több sajtómegjelenés. Utóbbit elősegítvén a weboldal ezen menüpontja alatt az újságírók könnyen, gyakran letölthetó formában érhetik el a jó hírértékkel rendelkezô, leközölhetô témákat ${ }^{14}$. Annak ellenére, hogy a történések megosztásának ma már számtalan lehetséges helye és platformja akad, érdemes mind a blog-, mind a sajtótartalma-

\footnotetext{
${ }^{13} \mathrm{https} / / /$ carbona.hu/

${ }^{14} \mathrm{Az}$ Aquaworld Resort Budapest honlapján (https://www.aquaworldresort.hu/) például sajtóanyagot találhatunk egy 2011-ben lebonyolított rendezvényről, amikor is sajtóesemény keretein belül ajándékozták meg az élményfürdő egymilliomodik látogatóját. A letölthető sajtóanyag végén megjelenik egy felhívás, miszerint az erről a témáról cikket író újságírók között a szálloda kisorsol egy két fö részére szóló wellness hétvégét.
} 
kat folyamatosan frissíteni, hiszen a közösségi oldalak mellett a szálloda saját weboldala jelenti még ma is a tudatos utazók és a sajtó munkatársainak elsődleges információforrását.

A weboldal stílusbeli megjelenése, az információk könnyú kereshetósége vagy a foglalási rendszer egyszerúsége elsődleges befolyásoló tényezói a potenciális vendégben kialakuló képnek, valamint a fogyasztói döntésnek. Éppen ezért a szakembernek a szálloda kommunikációs és megjelenésbeli stílusához, sugallni kívánt minőségéhez igazodva szükséges kialakítania a honlapot.

\subsection{A KÖZÖSSÉGI OLDALAK, MINT A VENDÉGKAPCSOLATOK ERÖSÍTÖI}

A Web 2.0 közösségi jellegének legalapvetőbb megnyilvánulási formái a közösségi oldalak. Az online kommunikáció térnyerésével a szolgáltatók közösségi platformokon való megjelenése elengedhetetlen a vállalat fenntartása érdekében, hiszen az utazók információkeresési és döntéshozatali tevékenységében ezen oldalak igen nagy szerepet játszanak, mindemellett a vállalkozás és a vendég közötti interakció kiemelkedő felületei (ZENGGERRITSEN 2014).

A Facebook-nak, amely hazánkban a legismertebb és legszélesebb körben használt közösségi oldal, a MediaQ piackutatási intézet szerint 2017-ben már több mint ötmillió regisztrált magyar felhasználója volt (LÉVAI 2017). Ez alapján a szolgáltatók számára az egyik legnagyobb piacelérési lehetőséget ez a platform biztosítja. Bár eleinte a Facebook az írott szöveges posztok és üzenetek gyújtőhelye volt, a későbbiekben megnőtt a képes, majd a videós tartalmak szerepe ${ }^{15}$.

A Facebook nagy gondot fordít arra, hogy a magánszemélyek mellett a vállalatok is jelen lehessenek a közösségi oldalon. A vállalkozásoknak kialakított üzleti oldalak "Névjegy” (azon belül bemutatkozás és elérhetőségek), „,Szolgáltatások", valamint „Bolt” opciói lehetőséget teremtenek arra, hogy az adott szálloda a lehető legszélesebb körben mutassa be magát és szolgáltatásait. A Hotel Silverine Lake Resort esetében ezeken felül megtalálhatjuk a weboldalon is jelentkező, a vendéget „Virtuális sétára” invitáló menüpontot. A „Rólunk írták" menüpontjuk alatt megtekinthetjük a már elszállásolt vendégek értékeléseit, mégpedig a TripAdvisor - az egyik legismertebb turisztikai ér-

\footnotetext{
${ }^{15} \mathrm{~A}$ formátumok hangsúlyosságát jól tükrözik az egyes posztokra adott általános reakciók (kedvelések, hozzászólások, megosztások): egy videót integráló poszt az összes elért személy több mint 9\%-át, egy képpe feltöltött üzenet a célzottak 8.8\%-át, míg egy csak szövegből álló állapotmegosztás az elért felhasználók valamivel több mint 5\%-át aktivizálja (LÉVAI 2018)
}

tékelő oldal - adatait magába integrálva. Látható tehát, hogy a vállalkozás Facebook profilján az utazó ma már minden szükséges információt megtalál döntésének meghozatalához. Az üzleti oldal múködése ezen kívül olyan statisztikai adatokat biztosít az oldalak adminisztrátorai számára, amelyek modern piackutatási eredményekként is felfoghatóak. Segítségükkel az elértek demográfiai adatai, a weboldalra kattintások száma vagy akár az oldal előnézetének megjelenési aránya is nyomon követhetô, akár az oldal egészét, akár az egyes bejegyzések adatait tekintve.

A közösségi oldalak funkcióját figyelembe véve a jelenlét mellett elengedhetetlen az aktív kommunikáció a kialakított közösséggel (az oldalt kedveló felhasználókkal), amelyben például az időzített posztok nyújthatnak segítséget. A szállodák esetében az új ajánlatok bemutatására vagy a rendezvények ismertetésére - többek között - a közösségi oldal ezen funkciója szolgálhat megfeleló eszközként. A Hotel Silverine Lake Resort online munkáját megfigyelve látható, hogy az oldal egységességét szem előtt tartva az egyes posztok egy kiemelt címmel rendelkeznek, majd ezután következik tartalmuk kifejtése. A bejegyzésekhez kapcsolódik egy-egy kép vagy videó, amely a figyelemfelkeltés eszközeként jelenik meg. Fontos az egyensúly megtartása: a szakembernek nem szabad abba a hibába esnie, hogy az egységességre való törekvése miatt az oldal esetleg unalmassá váljon ${ }^{16}$.

Az interaktivitásnál járva ki kell térnünk a fogyasztói oldalra is. Mint azt már fentebb említettük, a közösségi média egyik jellemző alapvonása, hogy míg a vállalkozásoknak nagyobb teret ad kreativitásuk megélésében, addig a felhasználóknak is platformot biztosít véleményük szabadabb kifejezésére. A fogyasztók ezen visszacsatolási lehetôsége egyszerre jelent veszélyt és lehetóséget: a szálláshelyeket éró negatív kritika - azok megfelelő kezelése nélkül - hosszútávon a felépített arculat romlásához vezethet (HEDE-KELLETT 2012). Emellett azonban a visszajelzések lehetővé teszik a folyamatos fejlődést, az aktuális fogyasztói igényekkel való azonosulást és így a szolgáltatások stabilan jó minőségét. A visszacsatolások figyelembevétele nemcsak a szálloda mint profitorientált szervezet, sikeres előmenetelét segíti, hanem annak imázsát is befolyásolja, hiszen bizonyos elemeiről - a hitelességról, valamint a személyesség-

\footnotetext{
${ }^{16}$ A Facebook algoritmusváltozásai miatt a vállalkozások tartalmainak organikus - vagyis nem fizetett - megjelenése 2018-ban csökkent az átlagos felhasználók posztjainak megjelenési arányával szemben. A hátrány kiküszöbölésére több megoldás létezik: egyrészt az üzleti oldalakhoz csatolt csoportok, amelyekben nagyobb aktivitás érhető el, másrészt a fizetett reklámok és a kiemelt bejegyzések rendszeres használata (SOÓS 2018)
} 
ról - kialakított fogyasztói vélemények az effajta interaktivitás alapján is változhatnak.

Az interaktivitás másik, de ugyanolyan fontos aspektusa a kedvelések, hozzászólások, valamint megosztások által történő felhasználói cselekvés, amely a szájreklám modern változatának tekinthetô. A szájreklám jelentősége megkérdőjelezhetetlen, hiszen az emberek utazási döntései során a családtagok, barátok és ismerósök véleménye egy adott úti célról, szolgáltatóról mindig is befolyásoló tényezô volt. Emellett a szájreklám a manapság már sok esetben negatívan megítélt direkt reklámoknál is hatásosabbnak bizonyul ${ }^{17}$ (NYILASY 2006). Kifejezetten a megosztások (és közvetett formában a kedvelések és a hozzászólások) által az adott tartalom az egyes felhasználó ismerősi körében láthatóvá, fogyaszthatóvá válik. Ezáltal az online aktivitás - bár a médium beférkôzik a két személy közé - a szájról szájra történő reklámozás újgenerációs szerepét tölti be.

Az interaktivitás növelésére, valamint a wellness-szolgáltatások hirdetésére és értékesítésére kitúnő gyakorlat az eladásösztönzés marketingeszközének online használata. A Hotel Silverine Lake Resort Facebook oldalán 2017. december 1-jén egy karácsonyi nyereményjátékkal találkozhattak az érdeklódők, amelynek részvételi feltétele a poszt kedvelése és megosztása volt. Ezen felül a játékban benne foglaltatott az a kitétel is, hogy amennyiben a határidóig az oldal kedvelési száma eléri a 10.000 fót, egy helyett két nyertest sorsolnak majd ki. A játék nyereménye egy 2 főre szóló, 2 éjszakás voucher volt a szálloda részéról. A nyereményjáték 2000 kedvelést, több mint 1400 megosztást és körülbelül 2700 hozzászólást eredményezett. Az oldal posztjaira adott átlagos reakciók számához képest ez több tízszeres növekedést jelentett. Mind a kedvelések, hozzászólások, mind pedig a megosztások megjelentek a nyereményjátékban résztvevők ismerôseinek hírfolyamában, amely így a poszt (és a szálloda) nagyságrendekkel nagyobb megjelenését eredményezte.

Míg a szálloda honlapját úgy kell elkészíteni, hogy az egyedi és összetéveszthetetlen legyen, vagyis a weboldal lehetóséget biztosít a hotel online imázsának szabad kialakításához, addig a Facebook jóval sematikusabb kereteket nyújt. A Facebook imázsépítő funkciója - magán a jelenléten felül - inkább az ott megjelenített személyesebb hangvételú tartalmakban és az interaktivitásban rejlik. A potenciális vendégekkel (felhasználókkal)

\footnotetext{
${ }^{7}$ A szájreklám kiemelt szerepét támasztja alá egy 2018 áprilisában készítet kérdőíves kutatásunk is. Bár a kutatás nem volt reprezentatív, a megkérdezettek jelentős hányada a wellness-szálloda kiválasztásakor fontos tényezőként említette a rokonok, barátok, ismerősök ajánlásait, valamint a korábbi vendégek véleményét, értékeléseit (LENGYEL 2018).
}

kialakított, a médium jelenléte miatt ugyan közvetett (vagyis mediatizált), formáját tekintve mégis közvetlen személyes kommunikáció hozzájárul a szálloda jó megítéléséhez.

Szintén népszerú - több mint egymillió felhasználóval rendelkezik hazánkban - az Instagram kép- és videómegosztó felület (LÉVAI 2017). Éppúgy, mint a Facebook esetében (az Instagram a Facebook leányvállalata), a vállalkozásoknak itt is lehetôségük van üzleti oldal kialakítására, amely révén olyan statisztikai információkhoz juthatnak, amelyek mindennapi piacelemzésként is értelmezhetőek. Az Instagram használata képközpontúsága miatt a turizmusban, azon belül is a szállodák és wellness-szállodák esetében, kimondottan előnyös, mivel a hotel minőségi berendezése és kiforrott, jól érzékelhető stílusa - tehát összességében külsó megjelenése - általában az elsó számú preferenciaként jelenik meg a vendégek utazási döntéseiben. Szerkezetét és múködését tekintve jelenleg az Instagram az egyik legalkalmasabb felület az online térben történő sikeres imázsépítésre ${ }^{18}$.

Az Instagramon megjelenő fotók három kategóriába sorolhatók: az alkalmi, a professzionális és a megtervezett fényképek csoportjaiba. Míg az alkalmi képek mindennapi történéseket örökítenek meg, s főleg az átlagfelhasználókhoz kötődnek, addig a professzionális képeket „eltúlzott kompozíciók, színek, részletek jellemzik" (GLÓZER 2018:227-228). A megtervezett képek letisztultak, a nagyvárosi élet metaforáiként vannak jelen. Ez főleg a fiatalok körében kedvelt képkészítési forma (MANOVICH 2017). Az elemzett szállodák Instagram felületeit vizsgálva a legjellemzőbb fotótémák a vízzel kapcsolatos szórakoztató tevékenységek (NaturMed Hotel Carbona), illetve a szálloda ételkínálatának esztétikus bemutatása (például Thermal Hotel Visegrád). A képek gyakran személyközpontúak, vagyis a készítők igyekeznek embereket megörökíteni, ezzel is természetesebbé téve az élményt. Hangsúlyosak a pillanatképként beállított fotók is. A megtervezett képek térnyerése ellenére a szállodák nagyrészt a professzionális fényképezés stílusát követik erősen megkomponált, színes, éles kontrasztú fotóikkal, amelyek alkalmasabbnak tû́nnek a hangulatok erôteljesebb átadására. Megfigyelhetó a trend, hogy a legtöbb utazással foglalkozó Instagram oldal is ilyen professzionális képeket oszt meg.

Az elóször az Instagramon megjelenó címkézés, vagyis a "hashtag"-ek használata a platform

\footnotetext{
${ }^{18}$ 2017-ben az Instagram már 25 millió üzleti felhasználóval rendelkezett, valamint 2016 és 2017 között az oldalon hirdetők száma egymillióra emelkedett (GLÓZER 2018).
} 
lényegi részét képezi ${ }^{19}$. A címkézés célja, hogy az adott hashtaggel ellátott képeket a platform egy helyen összpontosítsa, így egy konkrét címkére történő keresés során a felhasználó minden olyan tartalmat megtalál, amely (legalábbis a címke szerint) releváns a témában (GLÓZER 2018). A hashtagek több ízben való használata lehetóvé teszi a vállalatok számára, hogy a felhasználók minél több helyen (minél több témában) érhessék el tartalmaikat, valamint hogy a vendégek által készített fotók és videók, illetve a szálloda által feltöltött tartalmak egy helyen legyenek megtalálhatóak. A Hotel Silverine Lake Resort Instagram felületén minden tartalmának feltöltésekor a "hotelsilverine" hashtaget használja, s a címke alatti tartalmakat szemügyre véve számos vendég is ezt teszi. Egy-egy hashtag következetes használata ideális esetben a felhasználókat is a címke alkalmazására sarkallja, amely a vállalkozás számára segítséget nyújt a már elszállásolt vendégek által megtapasztalt élményminőség, valamint - a képek témája alapján - a látogatók preferenciájának felmérésére, miközben a fogyasztók egyszerre láthatják a szálloda által közölt képeket, valamint a vendégek értékelésszerú tartalmait ${ }^{20}$.

A keresôoptimalizálás eredetileg a keresési rendszereknél megjelenő tevékenység volt, de az Instagram is használja ezt a funkciót. A keresőoptimalizálás a vállalat részéról azt a célt szolgálja, hogy például a "balatonfüred” címkére keresve a felhasználó az elsők között láthassa a szálloda ezzel a hashtaggel ellátott tartalmát ${ }^{21}$. Az Instagram algoritmusa a találati sorrend meghatározásához számos ponton elemzi az oldalakat, például követơik száma, az oldalak által követett más oldalak minősége vagy a megosztott tartalmak által generált interakciók mennyisége alapján (DRAGONSEBESTYÉN 2017). Ebból jól látszik, hogy a találati

\footnotetext{
${ }^{19}$ A hashtaghez hasonló funkciót lát el a „location tag” használata is. A location tag, vagyis a helyszín címkéje a felhasználó neve és a megosztott kép között jelenik meg. Egy adott location tag alatt, hasonlóan a hashtaghez, az adott helyszínről készült összes kép megtalálható (GLÓZER 2018).

${ }^{20}$ Az elszállásolt vendégek fotózásra való hajlandóságát maga a vállalkozás is növelheti azáltal, hogy kreatív módon ajánl fel fényképezésre alkalmas helyeket vagy eszközöket. Erre jó példa a már sok helyen megjelenő Instagram-keret, amely mögé beállva a vendég olyan képet készíthet magáról, amely úgy tünik, mintha már eleve egy Instagramon megjelent fotó lenne.

${ }^{21}$ Az úgynevezett „hashtag-kampányok” célja a megjelenések számának növelése, összekötve azt egy jutalommal. Lényegében a felhasználók megosztási aktivitását igyekeznek kihasználni. A kampány felhívása lehet például, hogy a vendégek a szállodai szolgáltatások igénybevételekor készítsenek egy-egy képet/videót, és feltöltésük alkalmával használjanak egy megadott hashtaget. A kampány hashtagjének teljesen egyedinek kell lennie. A legjobb tartalmak előállítóinak jutalma lehet például egy a hotel által felajánlott voucher vagy - nagy követőtáborral rendelkező oldalak esetében - a kép/videó kihelyezése az üzleti oldalra.
}

sorrendben való optimális elhelyezkedés az üzleti oldal színvonalától függ, vagyis az Instagram ezen funkciója egyértelmúen a szervezet imázserősítő tevékenységét motiválja.

Az Instagram imázsformáló hatása a wellness-szállodák esetében tehát annak képiségében rejlik: mai társadalmunk a vizualitás terén egyre nagyobb igényekkel lép fel, amelyek kielégítésére ezen platform kitûnô lehetőséget biztosít. A wellness-szállodák szolgáltatásainak megfoghatatlanságát, az élményminőséget és a hitelességet kiválóan reprezentálják a felületre feltöltött képek, amelyek több irányból is érkezhetnek, így az átlagfelhasználóktól, az „utazó bloggerektől”, más területeken tevékenykedő influencerektől, s természetesen magától a szálláshelytől is. A tartalmak sokrétú megjelenésével a szálloda potenciális vendégköre is bóvülhet (GLÓZER 2018).

\subsection{REJTETT LEHETŐSÉGEK: A GOOGLE CÉGEM ÉS A LINKEDIN}

A weboldal és a közösségi média felületek mellett léteznek olyan platformok is, amelyeknek marketingkommunikációs potenciáljuk ugyan nem szembetúnő, megfeleló használat mellett azonban hatékonynak bizonyulhatnak. A vállalkozás egységes és kiegyensúlyozott arculatának kialakítását segíti elő közvetett formában például a Google Cégem rendszerében történő regisztráció. A platformon való részvétel azt eredményezi, hogy a Google Térképen a vállalkozás kereshetővé és láthatóvá válik, valamint a Google keresőrendszerében a vállalat nevére keresve annak adatai rögtön megjelennek a találati lista legtetején, vagy - amennyiben van ilyen - a szálloda hirdetései alatt (mobiltelefonon), illetve a képernyő jobb oldalán (asztali gép használata esetén). A nyitvatartás megtekintése, az elérhetóségek közvetlen használata (hívás, e-mail írás) vagy éppen az útvonaltervezés is lehetóvé válik ezáltal a fogyasztó számára, de akár azonnali szobafoglalás is lehetséges. A vendégvélemények manapság döntő befolyással bírnak a vállalat megítélésére, s a Google Cégem rendszerén keresztül szintén van lehetốség ezen reakciók megjelenítésére. A szolgáltatás ezen felül olyan statisztikai adatokkal látja el a regisztrált vállalkozást, mint hogy az adott látogató honnan jutott el a cég adatlapjához, vagy hogy melyik a vállalkozás adatlapjának legtöbbször megtekintett információja, tehát melyiket érdemes a leginkább aktualizálni és hangsúlyozni. Az értékesítést elősegítendő a vállalkozásnak lehetősége nyílik új ajánlatai megjelenítésére is. A tanulmányban szereplő szállodák - kereséseink alapján - mind rendelkeznek Google Cégem fiókkal. A NaturMed Hotel Carbona adatlap- 
ján a fent említett információk mellett még egy - a szállodáról szóló - Wikipédia szócikk részletét is elolvashatja az érdeklődő. A Google Cégem fiók tehát egyszerre tölti be az elérést növelő, az értékesítést elősegítő, valamint közvetetten ugyan, de az imázserősítő funkciót.

A közösségi felületek egy speciális, üzleti részét képezi a LinkedIn. Hasonlóan a Google Cégemhez, a LinkedIn imázsépítésre irányuló funkciója sem látható közvetlenül, azonban - kapcsolatépítésre alapozott felépítésének köszönhetően - közvetett formában mégis kitúnik az imázsra gyakorolt hatása. A LinkedIn lényegében egy önéletrajzokat összesítő platform, amelynek célja, hogy a munkáltatókat és a lehetséges munkavállalókat összekösse, valamint a vállalkozások vezetóinek teret biztosítson kapcsolathálójuk kiszélesítésére. A regisztrált felhasználó profilja az önéletrajza adataiból áll. Az elemzett wellness-szállodák közül a NaturMed Hotel Carbona, a Thermal Hotel Visegrád, valamint az Aquaworld Resort Budapest rendelkezik LinkedIn fiókkal. Utóbbi bemutatkozásában a konferencialehetôségeit emeli ki, angolul, felismerve azt, hogy a LinkedIn a cégek HR-, PR-, illetve marketingfelelőseinek fontos felület lehet a vállalat eseményeinek megszervezésében.

A LinkedIn esetében is látható tehát, hogy az imázsépítés sokkal inkább magán az „ott megjelenésen" alapszik, valamint a vállalkozások vezetőinek ideálisan széles körú kapcsolati hálóján. A LinkedIn használata a szakmán belül pozitív imázst teremthet a vállalkozásnak, amely a partneri kapcsolatok, valamint a manapság megjelenő co-opetition - vagyis az egymással kooperáló versenytársak kapcsolatának - kialakítását segítheti elő. Ezen kíviul a reklámtevékenységnek, mint például a konferencialehetőségek bemutatásának, fontos és releváns platformot biztosít.

\subsection{INNOVATÍV MEGOLDÁSOK: AZ AUDIOVIZUÁLIS TARTALMAK ÉS AZ EGYÜTTMÜKÖDÉSEK HATÉKONYSÁGA}

A szolgáltatók YouTube-on való megjelenése a videós tartalmak térnyerése miatt fontos újgenerációs marketingkommunikációs eszköz, amely kiváló lehetőséget biztosít a potenciális látogatók elérésére. A platform közel négymilliós hazai felhasználói bázisát tekintve, valamint figyelembe véve, hogy a magyar internetezók 49\%-a néz naponta videós tartalmakat, ezen felület hatékonysága - megfelelő használat mellett - szinte megkérdőjelezhetetlen (LÉVAI 2017, 2018). Kifejezetten a wellness-szállodákat tekintve, amelyeknek külsó megjelenése és szolgáltatásai elsődleges szempontok, az utazó gyakran szeretne egy mozgó, életszerú bemuta- tást látni a felkeresni kívánt szálláshelyről. A wellness-szolgáltatások megfoghatatlansága csökkenthető a videók segítségével.

$\mathrm{Az}$ online térben a PR egyik leghatékonyabb része az imázsvideók készítése. Az elemzett szállodák imázsvideóit megvizsgálva egyrészt olyan tartalmakat találunk, amelyek mintegy mozgóképes galériaként, központi szereplő nélkül igyekeznek a hotel egyes részlegeit bemutatni. Ilyen például a Thermal Hotel Visegrád (40.000 megtekintés) és a Caramell Premium ResortResort legnézettebb imázsvideója. Ezen felül egy másik típus is jól kirajzolódik: ez inkább a szolgáltatások bemutatására koncentrál, amelyek megismerésében narráció segíti a nézôket. A NaturMed Hotel Carbona több mint 47.000 megtekintést eredményezó egyik videójában Hévizet is bemutatja, hasonlóan a Hotel Silverine Lake Resorthoz, amely Balatonfüred látványosságait említi meg a wellness-szolgáltatások szemléltetése mellett. A legtöbb, félmillió körüli megtekintést elért imázsvideó (We create memories címmel) az AquaWorld Resort Budapest saját YouTube csatornáján található meg. A felvétel körülbelül másfél perces, tartalmában pedig a szolgáltatások részletes bemutatása helyett a hotel által kínált élmények dominálnak, amelyeket egy pár szemén keresztül közvetítenek, miközben az életszerú bemutatást fiatalos zene kíséri. A rövid videó könnyen fogyasztható, személyközpontú, s ezáltal közelebb hozza az élményt a nézőhöz. A szállodakomplexum emellett teljes egészében kihasználja a YouTube nyújtotta lehetőségeket. A médiakonvergencia jelenségét jól reprezentálja, hogy a csatornán megjelennek egyebek mellett azok a felvételek is, amelyek eredetileg televíziós músorok számára készültek, mint például a Poggyász magazinba szánt riport. Ezen kívül találkozhatunk szolgáltatásokat bemutató reklámfilmekkel, rendezvények összefoglalóival, sőt olyan - direkten a vásárlóknak gyártott - tartalommal is, amely például a szálloda ajándékutalványainak megrendelésében nyújt segítséget. Látható tehát, hogy az aktív YouTubejelenléttel a vállalkozás sokakat elérhet, legyen szó akár a szálloda részleg-, szolgáltatás- vagy élményközpontú bemutatásáról. Az imázsvideónak (és a többi tartalomnak) megfelelően kell közvetítenie az adott hotel hangulatát, stílusát, központi célját: legyen az akár az aktív időtöltés vagy a pihenés egy letisztult és kifinomult környezetben, akár egy lendületes, fiatalos üdülés. A jól szerkesztett videós tartalmak alkalmasak a szálloda potenciális érdeklődőkkel való megismertetésére, és rögtön a hotel meglátogatására is buzdíthatják a nézőket.

Mivel a YouTube is közösségi felület, az interaktivitás itt is alaptényezô. Bár a kommentszekció az egyes videók beállításainál letiltható, ez mégsem 
javasolt, hiszen akkor épp az imázsépítés hatékonyságát tükröző reakciók megfigyelése és mérése válik lehetetlenné. Tekintve, hogy a magyar felhasználók naponta átlagosan két órát töltenek el a platformon, valamint hogy a videós tartalmak népszerúsége töretlenül növekszik, a YouTube használata egyértelmú versenyelőnyt jelent a szállásadók számára ${ }^{22}$.

A közösségi felületekhez szorosan kötődő influencer marketing a marketingkommunikációs eszközök legújabb, s minden bizonnyal ma már egyik leghatásosabb válfaja. $\mathrm{Az}$ influencert ${ }^{23}$ tekinthetjük egyfajta véleményvezérnek, aki hatással van vagy befolyással bír személyek egy közösségére. $\mathrm{Az}$ influencer a korábbi sztár (amely a filmiparban jeleskedô személyek megnevezése volt), illetve celeb (azon személyek, akik a tabloidizációval egy időben jelentek meg) fogalmak mellett egy új keletú jelenség: ezek a do-it-yourself (csináld magad) celebek "hétköznapi hírességekként” foghatóak meg igazán. A hétköznapiság személyükben rejlik, tehát olyan egyénekről beszélünk, akik amatôr, gyakran otthoni körülmények között gyártott, hétköznapi témákról szóló tartalmaikkal tettek szert hírnévre az új médiában (GLÓZER-GULD 2015). Az influencerek elsődleges megjelenési felülete a YouTube, az Instagram és a Facebook, de influencer szerepet tölt be számos olyan celeb is, aki a hagyományos tömegkommunikációs csatornák által, illetve más, szakmához kötődő tevékenysége során tett szert hírnevére, s ezt építi tovább az új médiában. Hogyan aknázhatják ki a marketingszakemberek az influencer jelenség lehetôségeit?

„Mobil OFF, élmény ON" - szól a kampánysorozat szlogenje, amelynek ötlete Szántó Mónika, az Aquaworld Resort Budapest PR-osának nevéhez fúződik. A kampány célja, hogy felhívja a figyelmet a fiatal generáció digitális eszközhasználatának negatív következményeire, és egyben alternatív szabadidős programokat nyújtson. A programsorozat első eseményére olyan hazai influencereket hívtak meg, akik maguk is az online platformok segítségével érték el sikereiket, azonban - a pódiumbeszélgetések során - az online és az offline világ közötti egyensúly megtalálására ösztönözték a közel 2000 fő́t számláló közönséget ${ }^{24}$. A kampány sikeressége a közösségi felületeknél már említett, az influencerek által közvetített, szájreklámon alapult. Az esemény egyrészt az influencerek se-

\footnotetext{
${ }^{22}$ http://www.digitalhungary.hu/kozossegi-media/Kiderult-mennyireYouTube-fuggok-a-magyar-fiatalok/5250/

${ }^{23}$ Guld Ádám 2018-ban megjelent tanulmányában a Forbes magazin egy korábbi cikke alapján az influencerek hét típusát különbözteti meg. M kifejezetten a platform-specifikus influencerekkel foglalkozunk, akik leginkább kimerítik a „hétköznapiság” kategóriáját (GULD 2018).

${ }^{24} \mathrm{https} / / / \mathrm{www}$. aquaworldresort.hu/
}

gítségével terjedt el, akik megjelenésük és saját tapasztalataik megosztása révén hírét vitték a programsorozatnak és ezáltal a hotelnek. Másrészt a szlogen elterjedése (,mobil OFF, élmény $\left.\mathrm{ON}^{\prime \prime}\right)$ is a szájreklám modern formájának, az online aktivitásnak köszönhetó, amely ugyancsak hozzájárult a szálloda által rendezett eseménysorozat sikerességéhez. A szálloda ezen felül a társadalmi felelősségvállalás tevékenységén belül is jelentôs eredményeket ért el kampányával, amely ugyancsak a PR egyik fontos részterülete.

A fent említett példán túl, ahol az influencert vendégként hívták meg egy eseményre, a véleményvezérek gyakran jelentetnek meg felületeiken videós, képi vagy írott tartalmakat. Videós tartalomra kiváló példa Viszkok Fruzsi, az influencer közösség élvonalában járó vlogger, aki a Caramell Premium Resort számára készített imázserósító funkcióval bíró anyagot, amelyet ezután saját csatornáján jelentetett meg ${ }^{25}$. A videóban bemutatja a szállodai szobáját, valamint a wellnessrészleg egyes szolgáltatásait. A videóban a hotel neve nem hangzik el, az utazást inkább csak egy átlagos wellness pihenésként mutatja be, azonban a videó leírásában megtalálhatjuk a szálloda nevét, valamint weboldalának linkjét (ez alapján tartalommarketingnek is nevezhetjük). A szálloda, valamint azon belül is a wellnessrészleg ilyen formán történő bemutatása több szempont miatt ideális. Elsőként, mint ahogyan az egyébként is elterjedté vált, a szolgáltatásokat egy személy szemszögéből ismerhetjük meg, amely nagyobb hitelességet ad az élményminőségnek, mintha azokat csak önmagukban, a tárgyi feltételekre alapozva mutatnák be. Ehhez hozzátevődik a bemutató személye, tehát az influencer véleményvezérségből adódó befolyásoló ereje. Ezen felül a tartalom visszakereshetősége lehetóséget teremt arra, hogy a videó „örök életú" és ezáltal bármikor elérhetố legyen, szemben például az egyszer megrendezett eseményekkel. Mindemellett az anyagot, a véleményvezér követôtáborán túl, a szállodáról a YouTube-on informálódó potenciális vendégek is elérhetik. Ez a Viszkok Fruzsi-videó 400.000 megtekintés fölött jár (összehasonlításképp: a szálloda saját YouTube csatornáján a legnézettebb videó 42.000 megtekintést ért el).

$\mathrm{Az}$ influencerek megjelenése a marketingkommunikációs tevékenységben több szempontból is előnyös és hatékony. Egyrészt ahhoz, hogy valaki hatásos influencer lehessen, nagy, legalább ezres nagyságrendú (de inkább nagyobb) követő-

\footnotetext{
${ }^{25} \mathrm{Ne}$ feledkezzünk meg arról a jelenségrőll, hogy az interneten fellelhetö eszközök gyakran összekapcsolódnak. A vloggerként híressé vált Viszkok Fruzsi az Instagram felületén is több mint 300.000 követővel rendelkezik. A legyártott videókat így természetesen az Instagramon is promotálja.
} 
táborra van szüksége. Ez alapján az influencerek bevonása garantálja az elérések magas számát. Hatékonyságát elsősorban az influencerekbe vetett bizalom biztosítja, hiszen általában követőik hitelesnek tartják őket. A kommunikáció fókuszálhatósága is szabályozható a véleményvezéreken keresztül, akik gyakran egy témához kapcsolódóan gyártanak tartalmakat, s egy adott célközönségnek szánják anyagaikat. Ez alapján például egy utazásokkal foglalkozó vlogger, blogger vagy celeb kiváló választás lehet egy olyan szálloda részéról, amelyik az elérést a legkisebb szórással szeretné megvalósítani.

Az influencerekkel történő együttmúködésnek - a személyközpontúságból fakadóan - hátrányai is jelentkezhetnek. Ilyen lehet például a véleményvezér megosztó személyisége, akinek egy adott csoporttól származó rossz megítélése befolyásolhatja a kampány sikerességét. Fennáll továbbá a veszély, hogy a két fél a kampány célját, közvetítendő üzenetét nem tisztázza kellóképp, így az influencer az elvártaktól eltérő viselkedést és információkat közvetít a fogyasztók felé. Szintén kártékony lehet, ha az influencer az adott témát természetellenesen és feltúnően „reklámosítva” mutatja be. Erre példa egy Guld Ádám által készített elemzésben látható, aki éppen Viszkok Fruzsi kapcsán emeli ki, hogy az influencer miképp csorbítja saját hitelességét azzal, hogy a wellnesshétvégéről szóló videója elején az Orbit rágógumi kérésének is eleget téve, azt a vezetés kapcsolatos félelme ellen hatásos „eszközként” prezentálja. Guld szerint további problémát jelenthet az üzenet sikeres átadásában, ha a szponzorált tartalom az átlagfogyasztók szemszögéból elérhetetlennek túnik. Ezen felül az influencer követôi esetében megfigyelhetô egy olyan trend, hogy egy részük a feltöltött tartalmat csak szórakozásként tekinti meg, lényegi (marketing) üzenetével nem foglalkozik. Ez legfőképp a kommentszekcióban érhetô tetten, ahol gyakran lehet találkozni a nézőközönség irreleváns észrevételeivel, amelyek az influencereket körülvevő folyamatos diskurzus részei (GULD 2018). E veszélyek ellenére a marketingkommunikációs eszközök ezen elemének használata a vállalkozás számára egyértelmúen versenyelőnyt jelenthet, ráadásul a trendekkel való lépéstartás önmagában is egy a fejlődésre figyelmet fordító, a fogyasztói igényeket szem előtt tartó modern vezetési stílusról és vállalkozásról tesz tanúbizonyságot.

\section{4. Összegzés}

A tanulmány célja a Web 2.0 jelenségével egy időben megjelenô online platformok bemutatása, és funkcióik feltárása. A dolgozat a marketingkommunikáci- ós eszközökön belül főleg a PR-ra és azon belül is az imázsformálásra koncentrálva igyekszik bemutatni azon eszközöket, amelyek alkalmasak lehetnek a wellness-szállodák minél sokrétúbb megjelenésére.

$\mathrm{Az}$ internetes felületek és bôvülő funkcióik valóban számtalan lehetőséget biztosítanak mind a turisztikai szolgáltatók, mind a más területeken tevékenykedő vállalkozások számára üzeneteik minél sokszínúbb közvetítéséhez. A számos lehetőség ellenére azonban nem feledkezhetünk meg sem a tanulmány elején ismertetett integrált marketingkommunikáció jelentőségéről, sem a marketingkommunikáció modellszerú alapmozgásának elvéről. A kettő valójában összefügg: az integrált marketingkommunikáció alapja a marketingkommunikáció modellszerú alapmozgása, hiszen az utóbbiból adódó erősítő mechanizmus nélkül az egységesség (integráltság) nem is jöhetne szóba. A jó imázs kialakítása rendszerezett és összehangolt kommunikációt igényel, amelynek hatásossága, az online platformok ideális használatával, garantált az adott vállalkozás számára. Az internetes informálódás és az online foglalások előretörése miatt a (wellness) szállodák fô felületeivé a fentebb elemzett oldalak váltak (gondoljunk csak a televíziós vagy nyomtatott sajtós megjelenések csökkenésére), így az azokon való jelenlét ma már az imázsuk alapját jelenti. A versenytársak közül történő kiemelkedés, valamint az e célból létrehozott egyre egyedibb szolgáltatások megfelelő szintû́ (képi, audiovizuális) bemutatása és célzatos kommunikációja legoptimálisabban az online hálózatokon keresztül valósítható meg. Széles körú jelenlétével, személyes üzeneteivel és minél többek számára befogadható arculatával a vállalkozás képes lehet megdönteni a sokakban kialakult képet, miszerint a wellness egy elérhetetlen kikapcsolódási forma (LENGYEL 2018), így bővítve potenciális vendégkörét (természetesen a generációs különbségekre való tekintettel).

A posztmodern piacra jellemzó fogyasztói körök széttöredezettségéból fakadó kihívásokra, illetve Stephen Brown azon elképzelésére, miszerint „minden egyén egy különálló piaci szegmensként kezelendo"' (ÁRVA-DELI-GRAY 2018:281), a fentiek alapján ma már egyértelmúnek tûnik a megoldás. . A sokoldalúság és a fókuszálhatóság ilyen jelentôs mértékben még sosem volt jelen a marketingkommunikáció területén.

\section{Köszönetnyilvánítás}

A kutatást az EFOP-3.6.1-16-2016-00008 azonosítóval rendelkező, EU társfinanszírozású projekt támogatta. 


\section{Felhasznált irodalom}

ÁRVA L. - DELI-GRAY ZS. (2018): Posztmodern turizmus marketingtől a „big data" alapú marketingig: új típusú célcsoportképzési módszerek a turizmusban. In: Csapó J. - Gerdesics V. Törőcsik M. (szerk.): Generációk a turizmusban. I. Nemzetközi Turizmusmarketing Konferencia. Tanulmánykötet. Pécsi Tudományegyetem, Pécs. pp. 279-285.

BOROS SZ. - MONDOK A. - VÁRHELYI T. (2012): Az egészségturizmus szolgáltatásai és menedzsmentje. Szolnoki Főiskola, Szolnok. https://gk.uni-neumann.hu/images/tv-tanszek/ tantargyi-segedanyagok/boros_mondok_varhelyi_egeszsegturizmus_jegyzet.pdf, Letöltve: 2019. május 31.

GLÓZER R. - GULD Á. (2015): Új média - új típusú sztárok? A YouTube magyar hírességei. Információs társadalom. 15(2). pp. 34-54.

GLÓZER R. (2018): Jönnek az "Instagram-inasok"? $\mathrm{Az}$ Instagram szerepe és lehetóségei a turizmusmarketingben. In: Csapó J. - Gerdesics V. Törőcsik M. (szerk.): Generációk a turizmusban. I. Nemzetközi Turizmusmarketing Konferencia. Tanulmánykötet. Pécsi Tudományegyetem, Pécs. pp. 223-236.

GROTTE J. - KULCSÁR N. (2018): Szállodai élmény elvárások az Y és $Z$ generáció esetében. In: Csapó J. - Gerdesics V. - Törőcsik M. (szerk.): Generációk a turizmusban. I. Nemzetközi Turizmusmarketing Konferencia. Tanulmánykötet. Pécsi Tudományegyetem, Pécs. pp. 248-259.

GULD A. (2018): „Chillezzünk, beszélgessünk, áztassuk ki a testünket!" Mitól múködik az influencer kommunikáció a turizmusmarketingben? In: Csapó J. - Gerdesics V. - Törőcsik M. (szerk.): Generációk a turizmusban. I. Nemzetközi Turizmusmarketing Konferencia. Tanulmánykötet. Pécsi Tudományegyetem, Pécs. pp. 183-195.

GYULAVARI T. (2011): A CSR helye a marketing elméletben. In: Felelös marketing. MOK 17. Országos konferenciája. Responsible Marketing Conference Proceedings. Pécsi Tudományegyetem, Pécs. pp. 350-360.

HEDE, A.-M. - KELLETT, P. (2012): Building online brand communities: Exploring the benefits, challenges and risks in the Australian event sector. Journal of Vacation Marketing. 18(3). pp. 239-250.

KISS K. (2018): Az internet megjelenése a hazai turisztikai vállalkozások értékesítési és kommunikációs tevékenységében. In: Reisinger A. - Happ É. - Ivancsóné Horváth Zs. - Buics
L. (szerk.): "Sport-Gazdaság-Turizmus" Kautz Gyula Emlékkonferencia elektronikus formában megjelenő kötete. Széchenyi István Egyetem, Győr. pp. 1-12.

KITCHEN, P. J. (1997): Public Relations: Principles and Practice. Cengage Learning, Boston.

KITCHEN, P. J. - BURGMANN, I. (2010): Integrated Marketing Communication. In: Sheth, J. N. - Malhotra, N. (eds): Wiley International Encyclopedia of Marketing. pp. 1-23.

KOZMÁNÉ CSIRMAZ É. (2017): A magyarországi rekreációs turizmus egyes szegmenseinek elemzése a fogyasztói elégedettség szempontjából. Doktori (PhD) értekezés. Debreceni Egyetem, Gazdálkodástudományi Kar, Debrecen.

LENGYEL N. (2018): A magyarországi wellness szállodák marketingtevékenysége. Szakdolgozat. Szegedi Tudományegyetem, Bölcsészettudományi Kar, Kommunikáció- és Médiatudományi Tanszék, Szeged.

LŐKE ZS. - KOVÁCS E. - SIPOS E. (2016): A magyarországi wellness szállodák kínálatának jellemzői. In: Ivancsóné Horváth Zs. - Darabos F. (szerk.): "Turizmus és innováció" VIII. Nemzetközi turizmus konferencia 2016. Tanulmánykötet. Széchenyi István Egyetem, Győr. pp. 368-379.

LŐRINCZK.-SULYOKJ. (2017): Turizmusmarketing. Akadémiai Kiadó, Budapest.

MEERMAN SCOTT, D. (2015): The New Roles of Marketing and PR. John Wiley and Sons, Inc, New Jersey.

NYILASY, G. (2006): Word of Mouth: What We Really Know - and What We Don't. In: Kirby, J. - Marsden, P. (eds): Connected Marketing The Viral, Buzz and Word of Mouth Revolution. Butterworth-Heinemann, Oxford. pp. 161-184.

O'REILLY, T. (2007): What is Web 2.0: Design Patterns and Business Models for the Next Generation of Software. Communications $\mathcal{E}$ Strategies. 17(1). pp. 17-37.

POWER, D. J. - PHILLIPS-WREN, G. (2011): Impact of Social Media and Web 2.0. on DecisionMaking. Journal of Decision Systems. 20(3). pp. 249-261.

QI, S. (2016): Hotel Website Quality Versus Star Level: The Case of Macau Hotel Websites. In: Inversini, A. - Schegg, R. (eds): Information and Communication Technologies in Tourism 2016. Proceedings of the International Conference in Bilbao, Spain. pp. 325-338.

SCHANZE, V. H. (2001): Handbuch der Mediengeschichte. Alfred Kröner Verlag, Stuttgart.

SOÓS G. (2018): Digitális média tények könyve. Neo Interactive Kft., Budapest. 
SZAJBÉLY M. (2005): A médiatörténet és a sajtótörténet viszonyáról. Médiakutató. 2005 tavasz. https://www.mediakutato.hu/cikk/2005_01_tavasz/05_mediatortenet/, Letöltve: 2019. május 31.

SZIVA I. (2016): Az online értékesítés jelentősége a szállodaiparban. In: Sziva I. - Nemeslaki A.: Utazás E-Világban - Internet és versenyképesség a turizmusban. Információs Társadalomért Alapítvány, INFOTA Kutatóintézet, Budapest. pp. 74-81.

ZENG, B. - GERRITSEN, R. (2014): What do we know about social media in tourism? A review. Tourism Management Perspectives. 3(10). pp. 2736.

\section{Internetes források}

DRAGON Z. - SEBESTYÉN CS. (2017): A \#BREWkísérlet. SMART Konferencia, Budapest. http://digitalculture.hu/tevekenysegek/brew/, Letöltve: 2019. május 31.

LÉVAI R. (2017): Magyarok a közösségi médiában 2017 elején. http://kozossegikalandozasok. hu/2017/01/04/magyarok-a-kozossegi-mediaban-2017-elejen/, Letöltve: 2019. május 31.

LÉVAI R. (2018): Közösségi média adatok 2018. http:// kozossegikalandozasok.hu/2018/02/06/kozossegi-media-adatok-2018/, Letöltve: 2019. május 31.

MANOVICH, L. (2017): Instagram and contemporary image. http://manovich.net/index.php/ projects/instagram-and-contemporary-image, Letöltve: 2019. május 31.

\section{Elemzett tartalmak}

Accent Hotels weboldala: https://accenthotels.com/hu Aquaworld Resort Budapest LinkedIn profilja: https://www.linkedin.com/company/aquaworld-plc/about/

Aquaworld Resort Budapest weboldala, sajtósarok: https://www.aquaworldresort.hu/hu/aquaworld/sajtosarok

Aquaworld Resort Budapest - We create memories címú imázsvideója: https://www.youtube.com/ watch?v=zENIGcNnc2k

Bemutatkozik a NaturMed Hotel Carbona - imázsvideó: https://www.youtube.com/watch?$\mathrm{v}=8 \mathrm{UC}$-LcygMGs

Caramell Premium Resort imázsvideója: https:// www.youtube.com/watch? $\mathrm{v}=\mathrm{c} 8 \mathrm{tbm} 3 \mathrm{zqqHY}$

Harmónia Magazin - A Carbona blogja: https:// carbona.hu/blog/

Hotel Silverine Lake Resort Balatonfüred ${ }^{* * * *}$ superior weboldala: https://silverinelake.hu/hu

Hotel Silverine Lake Resort Facebook oldala: https://www.facebook.com/silverinelake/

Hotel Silverine Lake Resort imázsvideója: https:// www.youtube.com/watch?v=yI3zTAs8EEU

NaturMed Hotel Carbona Instagram oldala: https://www.instagram.com/naturmed_hotel_ carbona/?hl=hu

Thermal Hotel Visegrád image film 2014: https:// www.youtube.com/watch? $\mathrm{v}=\mathrm{CcnDuashE78}$

Thermal Hotel Visegrád Instagram oldala: https://www.instagram.com/thermalhotelviseg$\mathrm{rad} / ? \mathrm{hl}=\mathrm{hu}$

VLOG: Wellness hétvége | Viszkok Fruzsi: https:// www.youtube.com/watch?v=_iHBuXyfTHI 